\title{
Erythema ab igne as a complication of cannabinoid hyperemesis syndrome
}

\author{
Kamal Kant Sahu, ${ }^{1}$ Ajay Mishra, ${ }^{1}$ Leily Naraghi ${ }^{2}$
}

'Department of Internal Medicine, Saint Vincent Hospital, 123 Summer Street, Worcester, MA, 01608, United States ${ }^{2}$ Department of Emergency Medicine, Saint Vincent Hospital, 123 Summer Street, Worcester, MA, 01608, United States

\section{Correspondence to}

Dr Kamal Kant Sahu, drkksahu85@gmail.com

Accepted 7 December 2018

Check for updates

(C) BMJ Publishing Group Limited 2019. No commercial re-use. See rights and permissions. Published by BMJ.

To cite: Sahu KK, Mishra A, Naraghi L. BMJ Case

Rep 2019;12:e227836.

doi:10.1136/bcr-2018-

227836

\section{DESCRIPTION}

The legal status of cannabis is changing rapidly in the USA, Canada and other countries with medicinal use or recreational use becoming legal. ${ }^{1}$ With these new changes, there is an upsurge in the use of cannabis accompanied by increased frequency of complications such as cannabis hyperemesis syndrome (CHS). ${ }^{2-4}$ Erythema ab igne (EAI) is a dermatological manifestation resulting from skin exposure to excessive heat. It is commonly seen with the use of heating devices, laptop use, heating pads and so on. Here, we describe a frequent cannabis drug abuser who presented to emergency department (ED) with nausea, vomiting and unusual abnormal skin findings.

A 52-year-old man with a history of cannabis abuse came to ED with dizziness, vomiting and abdominal pain for 5 days. The abdominal pain was in the epigastric region, intermittent and burning in character. His medical records confirmed three previous ED visits and an admission for similar symptoms. During that admission, he underwent panel of investigations including complete blood count, liver/kidney function tests, serum lipase, contrast enhanced CT abdomen, upper GI endoscopy, colonoscopy, gastric emptying study which were normal. His repetitive cannabis use, recurrent episodes of nausea and vomiting, and normal diagnostic studies led to the diagnosis of CHS.

During the current ED visit, he had normal vital signs (temperature: $36.6^{\circ} \mathrm{C}$, heart rate: 88 beats/min, blood pressure: $131 / 89 \mathrm{~mm} \mathrm{Hg}$, respiratory rate: 18 breaths/min). Abdominal examination showed diffuse, erythematous skin rash, areas of variable hyperpigmentation with reticular pattern in upper half and skin foldimpressions in the lower half of abdomen (figure 1). On further inquiry, he reported taking hot showers and using heat pads over abdomen for symptom relief. Chemistry panel showed sodium $132 \mathrm{mmol} / \mathrm{L}$, potassium $2.9 \mathrm{mmol} / \mathrm{L}$, chloride $84 \mathrm{mEq} / \mathrm{L}$, bicarbonate $31 \mathrm{mEq} / \mathrm{L}$, BUN $34 \mathrm{mg} / \mathrm{dL}$ and creatinine $136.13 \mu \mathrm{mol} / \mathrm{L}$. Liver enzymes and lipase levels were normal. Urine toxicology screen was positive for cannabinoids. He was admitted and received $3.5 \mathrm{~L}$ of normal saline, $100 \mathrm{mmol}$ of potassium replacement and anti-emetics (two doses of $8 \mathrm{mg}$ inj. ondansetron followed by three doses of $2 \mathrm{mg}$ of inj. haloperidol). Over next 48 hours, his symptoms improved and was able to tolerate oral diet. He was counselled for permanent cannabis cessation and enrolled to drug de-addiction centre.

CHS is one of the complications of chronic cannabis use. In general, cannabis in lower doses is appetite stimulant and may reduce nausea. Physicians have reported benefits in nausea, general wellbeing, improvement in appetite and pain by using cannabis in patients with advanced cancer or AIDS. However, frequent and repetitive use of higher doses of cannabis produces high serum concentrations of cannabinoids with a paradoxical pro-emetic response. ${ }^{5}$ However, the strong belief about antiemetic effects of cannabis are so widespread that it is often difficult to convince patients that their cannabis use is the root cause problem for CHS.

Many CHS patients have stereotypic behaviour of compulsive hot showers for symptomatic benefits. ${ }^{6}$ Hot showers and use of heat pads are usually learnt behaviour, acquired over course of period which lead to EAI in our patient. In series of nine patients, Allen et al reported that degree of hotness of water was directly proportional to the symptom relief. ${ }^{5}$ In an attempt to gain maximum effect, two patients even suffered hot shower related scald burns. Recently, Dezieck et al postulated reason for 'Hot shower induced symptom relief in CHS'. Transient receptor potential vanilloid 1 (TRPV1 receptor) is a thermoreceptor located in emesis centre in the area postrema. ${ }^{6}$ Low ligand concentration on this receptor has pro-emetic property while persistent stimulation by high ligand concentration, high temperatures and capsaicin desensitises the receptor and initiates a paradoxical anti-emetic response. Based on this principle, Dezieck et al reported symptom control in all 13 CHS patients with the use of topical capsaicin. ${ }^{6}$

More research is warranted to delineate the public health implications of recreational marijuana use. As evident though our case, self treatment of CHS has risk of thermal injuries. ${ }^{5}$ The present case illustrates EAI as one of the rare thermal injuries suffered by CHS patients. EAI resembles like lacework or a fishing net resulting from thermal injury to superficial skin layers and vascular networks. Common differentials while considering EAI are cutis marmorata, telangiectatica congenita and livedo reticularis. Definitive treatment for EAI is removal of the source of excessive heat exposure. laser therapy, tretinoin and 5-Fluorouracil have been tried by dermatologists for cosmetic disfigurement with variable success rates. Rarely, cancer may arise from EAI lesion, hence frequent check up and close monitoring of skin rash for change in appearance, size, color and border characteristics is highly recommended. ${ }^{7}$ Study conducted in Denver Health Medical Centre, Colorado showed doubling of ED visits for CHS when compared before and after marijuana liberalisation. ${ }^{5}$ Similarly, in the study 


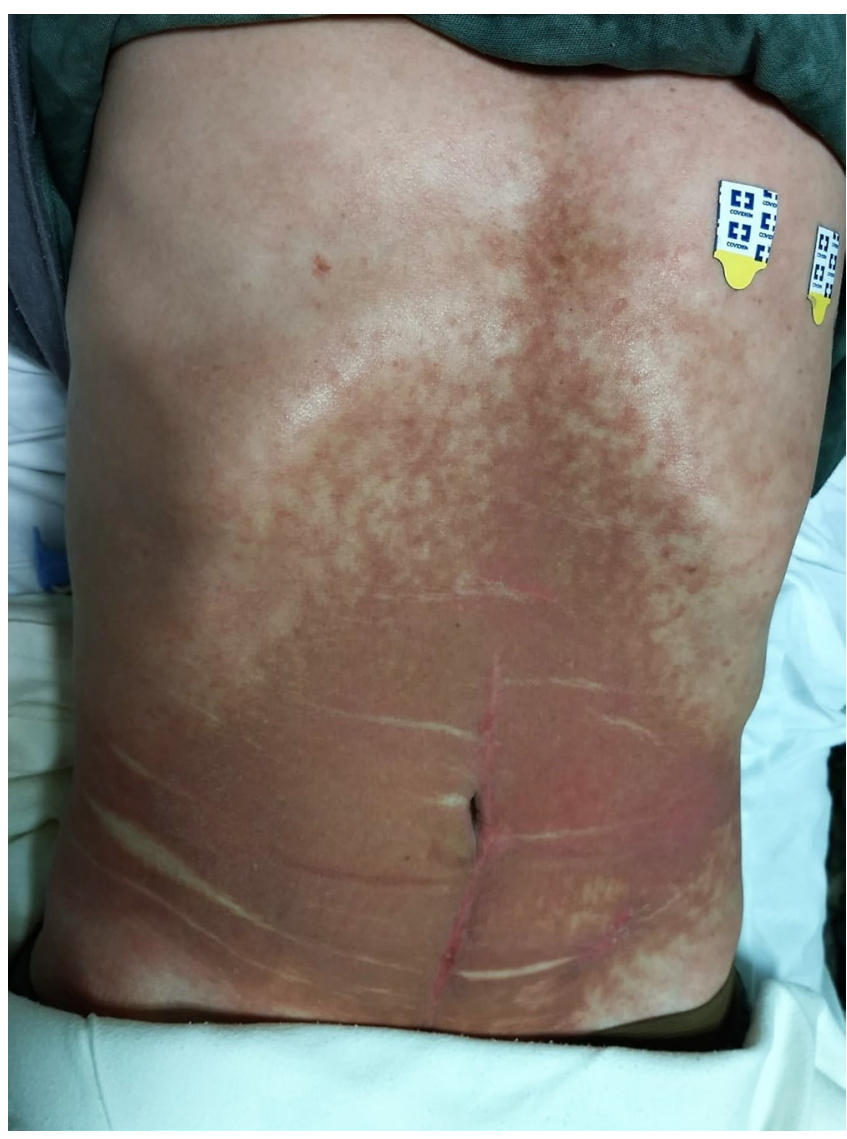

Figure 1 The image shows diffuse, erythematous skin burns without peeling or blisters covering the entire abdominal surface. There is a reticular pattern in the superior half and in the periphery of the erythematous area. Also, hypopigmented lines can be seen across the inferior half that suggest skin folds, folds of cloth in the area of the skin contact with the heat source or possibly the waistband of his underwear.

conducted in the University of Colorado burn centre, Monte et al reported a substantial increase in the number of marijuana-related burns in past two years. ${ }^{4}$

CHS symptomatology resembles with other causes of recurrent or cyclic vomiting such as addison's disease, hyperemesis gravidarum, diabetic gastroparesis, acute intermittent porphyria, gastric outlet obstruction and so on. ${ }^{5}$ Frequent cannabis use, temporary relief with hot showers, and non-diagnostic clinical investigations support the diagnosis. ${ }^{356}$
In CHS, phenothiazines and butyrophenones are more effective anti-emetics than ondansetron.Topical capsaicin may also be helpful in some cases. ${ }^{7}$ Awareness of dermatological side effects of various diseases and drugs can help clinicians manage their patients more efficiently. ${ }^{8-10}$ Definitive treatment of CHS is permanent abstinence from cannabis abuse. This becomes especially challenging when there is common notion among consumers that cannabis alleviates vomiting symptoms.

\section{Learning points}

- Frequent hot showers are common among patients with cannabis hyperemesis syndrome and asking specifically about this often adds a clue to the diagnosis.

- Long-term relief requires permament cessation of cannabis use.

Contributors KKS: Case writing and discussion, planning, reporting. AM: Photography, made legends and review of the manuscript. LN: Management, editing and review of literature, conception and design.

Funding The authors have not received any specific grant for this research from any funding agency in the public, commercial or not-for-profit sectors.

Competing interests None declared.

Patient consent Obtained.

Provenance and peer review Not commissioned; externally peer reviewed.

\section{REFERENCES}

1 http://www.governing.com/404?keywords=gov-data\%20safety-justice\%20statemarijuana-laws-map-medical\%20recreational.html\&referrer=

2 Furlow B. Recreational cannabis legalisation in the USA outpaces research into health effects. Lancet Respir Med 2017;5:385-6.

3 Kim HS, Anderson JD, Saghafi 0, et al. Cyclic vomiting presentations following marijuana liberalization in Colorado. Acad Emerg Med 2015;22:694-9.

4 Monte AA, Zane RD, Heard KJ. The implications of marijuana legalization in Colorado. JAMA 2015:313:241-2.

5 Allen JH, de Moore GM, Heddle R, et al. Cannabinoid hyperemesis: cyclical hyperemesis in association with chronic cannabis abuse. Gut 2004;53:1566-70.

6 Dezieck L, Hafez Z, Conicella A, et al. Resolution of cannabis hyperemesis syndrome with topical capsaicin in the emergency department: a case series. Clin Toxicol 2017;55:908-13.

7 Milchak M, Smucker J, Chung CG, et al. Erythema ab igne due to heating pad use: A case report and review of clinical presentation, prevention, and complications. Case Rep Med 2016;2016:1-3.

8 Sahu KK, Sawatkar GU, Jeyaraman P, et al. Bullae And Blisters: A Rare Case of Bendamustine Skin Toxicity. Indian J Hematol Blood Transfus 2016;32(Suppl 1):368-9.

9 Sahu KK, Varma SC. Herpes zoster complicating bortezomib therapy. Indian J Med Res 2015;141:247-8.

10 Sahu KK, Mishra A, Chastain I. Novel anticancers and dermatological adversities: old rivals but new challenges. BMJ Case Rep 2018;11:e227790.

Copyright 2019 BMJ Publishing Group. All rights reserved. For permission to reuse any of this content visit

https://www.bmj.com/company/products-services/rights-and-licensing/permissions/

BMJ Case Report Fellows may re-use this article for personal use and teaching without any further permission.

Become a Fellow of BMJ Case Reports today and you can:

- Submit as many cases as you like

- Enjoy fast sympathetic peer review and rapid publication of accepted articles

- Access all the published articles

Re-use any of the published material for personal use and teaching without further permission

For information on Institutional Fellowships contact consortiasales@bmjgroup.com

Visit casereports.bmj.com for more articles like this and to become a Fellow 